\title{
The recirculated aquaculture system (RAS) development with nanobubble application to improve growth performance of grouper fish fry culture
}

\section{Pengembangan recirculated aquaculture system (RAS) dengan aplikasi nanobubble untuk meningkatkan kinerja pertumbuhan benih ikan kerapu}

\author{
Iik Muslihul Hanif ${ }^{1}$, Irzal Effendi ${ }^{*}$, Tatag Budiardi', Iis Diatin ${ }^{1}$ \\ ${ }^{1}$ Department of Aquaculture, Faculty of Fisheries and Marine Sciences, IPB University, \\ Bogor, West Java, Indonesia 16680 \\ *Corresponding author: irzalef@apps.ipb.ac.id
}

(Received June 10, 2021; Accepted June 28, 2021)

\begin{abstract}
One of the aquaculture commodities with high economic value is grouper fish (Epinephelus sp.). RAS is known as one of superior and suitable aquaculture systems in juvenile fish culture. RAS installed with NBs is expected to increase the stocking density and production of hybrid brown-marbled grouper. This study aimed to analyze the system performance of grouper fish juvenile culture in high stocking density with water exchange system, RAS, and combination of RAS and NBs. This study used a factorial design with two factors, namely different stocking densities and cultivation systems. The densities were 500, 600 and $700 \mathrm{fish} / \mathrm{m}^{3}$, while the treatment systems were RAS without NBs, RAS installed with NBs, and control treatment with $200 \%$ water change. Each treatment was replicated three times. The total aquaria used for this study were 27 as each size was $1.5 \mathrm{~m} \times 0.5 \mathrm{~m} \times 0.5 \mathrm{~m}$. The study results showed that the RAS installed with NBs and a stocking density of $600 \mathrm{fish} / \mathrm{m}^{2}$ showed the best results on fish production performance.
\end{abstract}

Keywords: density, growth, grouper, nanobubble, RAS

\begin{abstract}
ABSTRAK
Pendederan ikan kerapu meripakan salah satu segmen dalam usaha budidaya ikan kerapu (Epinephelus sp.). Salah satu sistem akuakultur yang cocok yang dapat digunakan dalam pendederan ikan kerapu ini adalah sistem recirculated aquaculture system (RAS). RAS dengan instalasi nanobubble (NBs) ini diharapkan bisa meningkatkan padat tebar dan kinerja produksi benih ikan kerapu. Penelitian ini bertujuan untuk menganalisis kinerja sistem pendederan ikan kerapu dengan padat tebar tinggi berbasis sistem pergantian air, RAS, dan perpaduan antara RAS dan NBs. Rancangan percobaan yang digunakan dalam penelitian ini adalah faktorial dengan dua faktor, yaitu padat tebar dan sistem budidaya berbeda. Padat tebar yang digunakan adalah 500, 600, dan 700 ekor/ $\mathrm{m}^{3}$, sedangkan sistem budidaya terdiri dari RAS tanpa NBs, RAS dengan NBs dan kontrol (sistem pergantian air 200\%), setiap perlakuan terdiri dari atas tiga ulangan. Hasil penelitian menunjukkan bahwa pendederan menggunakan RAS dengan NBs dengan padat tebar 600 ekor/m² menunjukkan kinerja produksi ikan kerapu yang terbaik.
\end{abstract}

Kata kunci: ikan kerapu, kepadatan, nanobubble, pertumbuhan, RAS 


\section{INTRODUCTION}

Fisheries sector, including aquaculture, became one of the economic sectors that contributes to the National Gross Domestic Product in 2019 at $6.25 \%$ or $\mathrm{Rp} 62.24$ trillion as higher than in 2018 at $4.83 \%$ or $\mathrm{Rp} 58.58$ trillion. One of the aquaculture commodities that has high economic value and export-oriented product is grouper fish (Epinephelus sp.). This fish is exported alive to China, Singapore, Hong Kong, and Japan. The production center for grouper fish grow-out in Indonesia is distributed in several regions, namely Riau Islands, North Sumatera, Bangka Belitung, Jakarta, East Java, Bali, Maluku etc. This value chain condition above causes issues and problems of living fish transport, followed by time and place management that becomes important. Period and transport density, followed by water movement, waste accumulation, and packaging procedure influence the transported fish stress response (Shabani et al., 2016; Hong et al., 2019). The optimal time for living fish transport, mainly through air transport mode causes a repackaging and/or temporary transport, which causes an additional cost.

In grouper fish fry culture, the fish transport cost can be minimized by transporting the fish in smaller size and higher stocking density. These small fish are initially reared in juvenile culture system before entering the grow-out system using tank and floating net cage (Akbar et al., 2012; Effendi et al., 2021). Recently, a recirculation system has been developed or known as a recirculated aquaculture system (RAS) with less water consumption, high stability level that can be controlled, and the location is closed to the consumers. RAS is a culture system that recycles water through several filters and components to improve the water quality and reuse the water (Losordo et al., 2009).

Nanobubbles (NBs) are air bubbles with diameter less than $200 \mathrm{~nm}$ that can live longer and more stable in the water as the liquid internal pressure is higher than the environment which accelerates solubility (Eriksson et al., 1999; Agarwal et al., 2011; Matsuki et al., 2012; Ebina et al., 2013). In recent years, the nanobubble technology has been applied widely in science and technology sector, such as water processing, biomedical engineering, and nanomaterials (Agarwal et al., 2011). This technology has also been used in aquaculture sector to increase dissolved oxygen (DO), namely stimulating Nile tilapia Oreochromis niloticus and vaname shrimp Penaeus vannamei growth, besides decreasing the total pathogenic bacteria and modulating the host immune system against bacterial infection (Imaizumi et al., 2018; Mahasri et al., 2018; Mauladani et al., 2018; Dien et al., 2021; Linh et al., 2021; Nghia et al., 2021; Rahmawati et al., 2021). The development of RAS installed with $\mathrm{NBs}$ becomes one of the solutions to improve the grouper fish fry culture productivity through increased stocking density. This study aimed to evaluate the recirculation system production performance installed with NBs in hybrid brown-marbled grouper in high stocking density condition.

\section{MATERIALS AND METHODS}

\section{Experimental design}

The experimental design used in this study was a factorial design with two factors, stocking density and culture system, as each treatment was replicated three times (Table 1). The stocking densities tested were 500, 600, and $700 \mathrm{fish} /$ $\mathrm{m}^{3}$, while system treatments applied were RAS without NBs, RAS with NBs, and control (200\% water exchange). The stocking density treatments were developed from SNI 8036.2:2014 for hybrid grouper with $2.8-3.2 \mathrm{~cm}$ size at $250-350 \mathrm{fish} / \mathrm{m}^{3}$ in water exchange system.

Table 1. Experimental design

\begin{tabular}{lccc}
\hline \multirow{2}{*}{ Culture system } & \multicolumn{3}{c}{ Stocking density $\left(\mathrm{fish} / \mathrm{m}^{3}\right)$} \\
\cline { 2 - 4 } & 500 & 600 & 700 \\
\hline RAS without NBs & $5 \mathrm{R}$ & $6 \mathrm{R}$ & $7 \mathrm{R}$ \\
RAS with NBs & $5 \mathrm{RN}$ & $6 \mathrm{RN}$ & $7 \mathrm{RN}$ \\
Control & $5 \mathrm{~K}$ & $6 \mathrm{~K}$ & $7 \mathrm{~K}$ \\
\hline
\end{tabular}

Note: $5 \mathrm{R}=\mathrm{RAS}$ without NBs at $500 \mathrm{fish} / \mathrm{m}^{3}$ stocking density, $6 \mathrm{R}=\mathrm{RAS}$ without $\mathrm{NBs}$ at $600 \mathrm{fish} / \mathrm{m}^{3}$ stocking density, 7R = RAS without NBs at $700 \mathrm{fish} /$ $\mathrm{m}^{3}$ stocking density, $5 \mathrm{RN}=\mathrm{RAS}+\mathrm{NBs}$ at $500 \mathrm{fish} /$ $\mathrm{m}^{3}$ stocking density, $6 \mathrm{RN}=\mathrm{RAS}+\mathrm{NBs}$ at $600 \mathrm{fish} /$ $\mathrm{m}^{3}$ stocking density, $7 \mathrm{RN}=\mathrm{RAS}+\mathrm{NBs}$ at $700 \mathrm{fish} / \mathrm{m}^{3}$ stocking density, $5 \mathrm{~K}=$ Control at $500 \mathrm{fish} / \mathrm{m}^{3}$ stocking density, $6 \mathrm{~K}=$ Control at $600 \mathrm{fish} / \mathrm{m}^{3}$ stocking density, $7 \mathrm{~K}=$ Control at $700 \mathrm{fish} / \mathrm{m}^{3}$ stocking density.

\section{Culture technique}

The 27 units of aquarium with the size of 1.5 $\mathrm{m} \times 0.5 \mathrm{~m} \times 0.5 \mathrm{~m}$ were filled with seawater at $1000 \mathrm{~L}$. The seawater was disinfected using 30 $\mathrm{mg} / \mathrm{L}$ chlorine and neutralized by $75 \mathrm{mg} / \mathrm{L} \mathrm{Na}-$ thiosulfate, while being precipitated and aerated. 
A probiotic was also used at $5 \mathrm{mg} / \mathrm{L}$ in three days before stocking the fish. For RAS without NBs treatments (5R, 6R, and $7 R$ ), aquaria were equipped with aeration and filtration systems containing green woll, zeolith, bio ring ceramic, and bioball filters (Lawson, 1995). Aquaria for RAS with NBs (5RN, 6RN, and 7RN) were equipped with nanobubble regulator.

The hybrid brown-marbled groupers Epinephelus sp., produced from the cross-breeding of female brown-marbled grouper E. fuscoguttatus and male camouflage grouper E. polyphekadion at $3.51 \pm 0.05 \mathrm{~cm}$ (approximately on one-month age) were obtained from the breeding center in Situbondo, East Java and stocked in aquaria. Fish were stocked based on the treatments applied. The fish used were obtained after sortation and grading. The fish were acclimatized for three days in the experimental aquaria, cultured or 30 days, and fed with commercial sinking pellet diet at $1.5 \mathrm{~mm}$ size (48\% protein content) until apparent satiation to avoid canibalism. During the culture period, water exchange was performed at $10 \%$ in RAS and NBs treatments to replace the water loss due to evaporation.

\section{Parameters}

Grouper fish length and weight was measured every 10 days during 30 days of culture. Fish samples were taken at $10 \%$ of the total fish and measured using a scale with $0.01 \mathrm{~g}$ accuracy, while length measurement was performed using calipers with $0.01 \mathrm{~mm}$ accuracy. The weight and length data were collected to calculate the fish growth performance.

\section{Water physical-chemical parameters}

Parameters tested during the experimental period contained water physical-chemical contents ( $\mathrm{pH}$, salinity, dissolved oxygen, ammonia, nitrite, nitrate) and growth performance (survival rate, spesific growth rate, feed conversion ratio, and productivity) (Table 2). The temperature, $\mathrm{pH}$, salinity, and DO were measured directly everyday at $07.00 \mathrm{GMT}+7$. Meanwhile, ammonia, nitrite, and nitrate were measured every 10 days by taking the water samples from each aquarium at $07.00 \mathrm{GMT}+7$.

\section{Growth performance}

Survival rate level was determined at the end of culture period using the formula (Ye et al., 2020):
Table 2. Water quality parameters in the aquarium with and without NBs in different stocking densities.

\begin{tabular}{ccc}
\hline Parameter & Unit & Equipment \\
\hline Temperature & ${ }^{\circ} \mathbf{C}$ & Thermometer \\
Salinity & $\mathrm{g} / \mathrm{L}$ & $\begin{array}{c}\text { Refractometer } \\
\mathrm{pH}\end{array}$ \\
& $\mathrm{pH}$ meter \\
Dissolved oxygen & $\mathrm{mg} / \mathrm{L}$ & DO meter \\
Nitrite $\left(\mathrm{NO}_{2}^{-}\right)$ & $\mathrm{mg} / \mathrm{L}$ & Spectrophotometer \\
Nitrate $\left(\mathrm{NO}_{3^{-}}\right)$ & $\mathrm{mg} / \mathrm{L}$ & Spectrophotometer \\
Ammonia $\left(\mathrm{NH}_{3}\right)$ & $\mathrm{Mg} / \mathrm{L}$ & Spectrophotometer \\
\hline The
\end{tabular}

The $e x$-situ water quality measurement was performed in a laboratory of health and environment, Center for Brackishwater Aquaculture, Situbondo, East Java.

$$
\mathrm{SR}=\frac{\mathrm{N}_{\mathrm{t}}}{\mathrm{N}_{0}} \times 100
$$

Whereas, SR: fish survival rate (\%); Nt: total final fish; and No: total initial fish. The specific growth rate is an increased percentage of fish weight which was calculated with the formula (Wang et al., 2020):

$$
\mathrm{SGR}=\frac{(\mathrm{Ln} \mathrm{Wt}-\mathrm{Ln} \mathrm{Wo})}{\mathrm{t}} \times 100
$$

Whereas, SGR: Specific growth rate (\%/day); Wt: average final fish weight on t-period $(\mathrm{g})$; Wo: average initial fish weight on 0 -period (g); dan $\mathrm{t}$ : culture period (days). The feed conversion ratio was calculated using the following formula (Goddard, 1996):

$$
\mathrm{FCR}=\frac{\mathrm{F}}{\mathrm{Wt}+\mathrm{Wo}-\mathrm{Wd}}
$$

Whereas, FCR: feed conversion ratio; F: Total feed consumed $(\mathrm{kg})$; Wt: fish biomass on final culture period $(\mathrm{kg})$; Wo: fish biomass on initial culture period; Wd: dead fish biomass during the culture period $(\mathrm{kg})$. Fish length diversity was determined with the formula (Xie et al., 2011): Whereas, FLD: fish length diversity (\%);

$$
\mathrm{FLD}=\frac{\mathrm{S}}{\overline{\mathrm{x}}} \times 100
$$

S: standard deviation of fish length on each treatment; $x^{-}$: average of fish length on each treatment. Fish weight diversity was determined with the formula (Xie et al., 2011):

$$
\mathrm{FWD}=\frac{\mathrm{S}}{\overline{\mathrm{x}}} \times 100
$$


Whereas, FWD: fish weight diversity (\%); S: standard deviation of fish weight on each treatment; $x-$ : average of fish weight on each treatment. Biomass production in the system was calculated using the following formula (Saefulhak, 2004):

$$
\mathrm{P}=\frac{\mathrm{B}_{\mathrm{t}}}{\mathrm{L}}
$$

Whereas, P: productivity $\left(\mathrm{kg} / \mathrm{m}^{2}\right)$; Bt: biomass at the end of culture period $(\mathrm{kg})$; and $\mathrm{L}$ : tank surface area $\left(\mathrm{m}^{2}\right)$.

\section{Data analysis}

The data obtained were tabulated for the continued statistical analysis. The production performance parameter data were analyzed using the analysis of variance (ANOVA) at 5\% confidence degree. If the data were significantly different, Duncan's test was applied further. The business analysis and water quality data were analyzed descriptively using figures and tables. Data analysis was performed using Microsoft Excel 2016 and IBM SPSS Statistics 23.0 software program.

\section{RESULTS AND DISCUSSIONS}

\section{Results}

Water quality

The nanobubble regulator was installed along with the recirculation system at 500,600, and 700 fish $/ \mathrm{m}^{3}$ stocking densities (5RN, 6RN, and 7RN). This condition obtained the highest dissolved oxygen value for 30 days of culture period compared to other treatments, then declining slowly. The dissolved oxygen in other treatments tended to be stable until the end of culture period, namely $4.62-6.37 \mathrm{mg} / \mathrm{L}$ (Figure 1).

The $\mathrm{pH}$ measurement results during the culture period for 30 days obtained a decreased $\mathrm{pH}$ value tendency until the end of culture period, except in control treatment at 7.8-8.3. The lowest $\mathrm{pH}$ value was occurred in the $7 \mathrm{RN}$ treatment at 7.0 on the end of culture period. The highest $\mathrm{pH}$ value was occurred in all treatments, namely on the initial culture period of hybrid brown-marbled grouper at 8.2 (Figure 2).

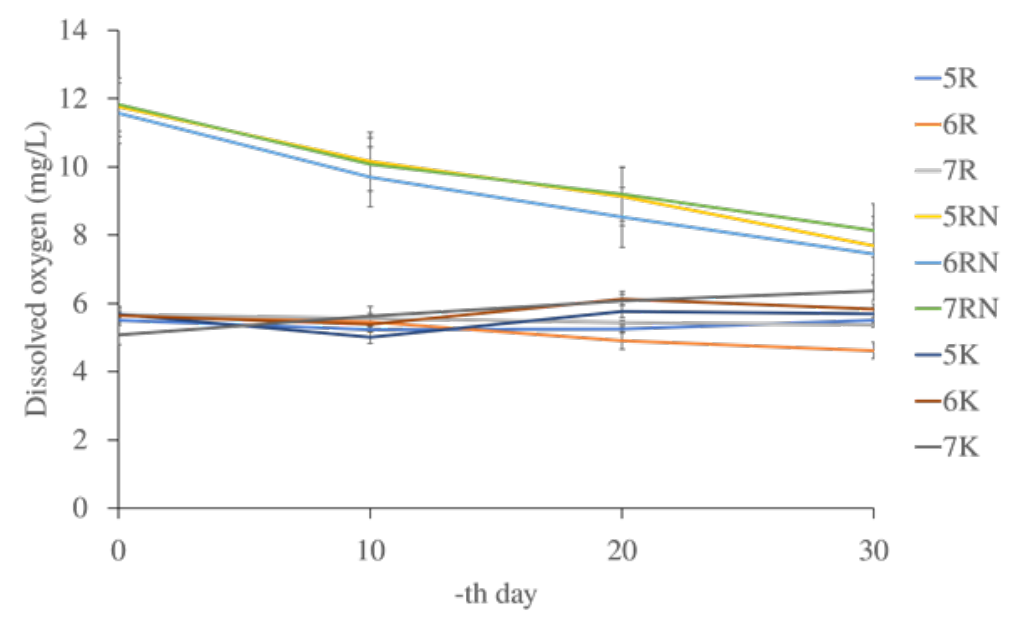

Figure 1. Dissolved oxygen level for 30 days of culture period in hybrid brown-marbled grouper

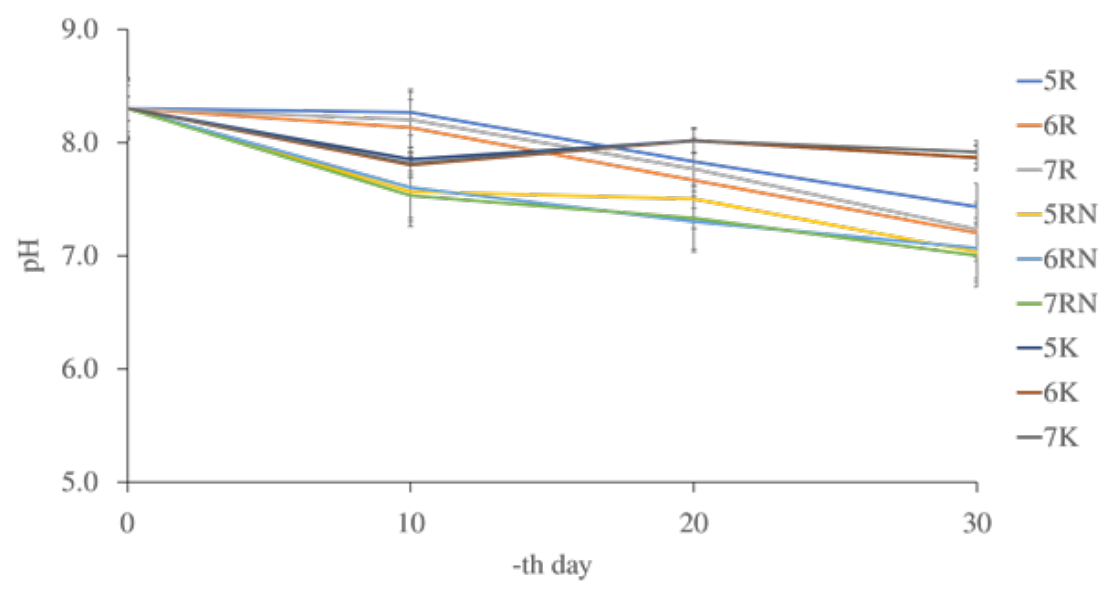

Figure 2. $\mathrm{pH}$ value during 30 days of hybrid brown-marbled grouper culture period 
The salinity measurement results during 30 days of culture period showed that all salinity values increased in all treatments based on Figure 3 . The highest salinity value increase was shown by all control treatments on the $20^{\text {th }}$ day at among $31.0-30.7 \mathrm{~g} / \mathrm{L}$ and on the $30^{\text {th }}$ day at $32 \mathrm{~g} / \mathrm{L}$. This figure below is the graphic of salinity level during the hybrid brown-marbled grouper culture period for 30 days (Figure 3 ).
The measurement results of ammonia, nitrite, and nitrate during hybrid brown-marbled grouper culture period on various applied systems and stocking densities demonstrated fluctuating values in RAS with and without nanobubble regulator. Ammonia, nitrite, and nitrate in control treatment tended to be stable and lower than other treatments. The graphic below describes the measurement results of ammonia, nitrite, and nitrate levels during 30 days of culture period (Figure 4).

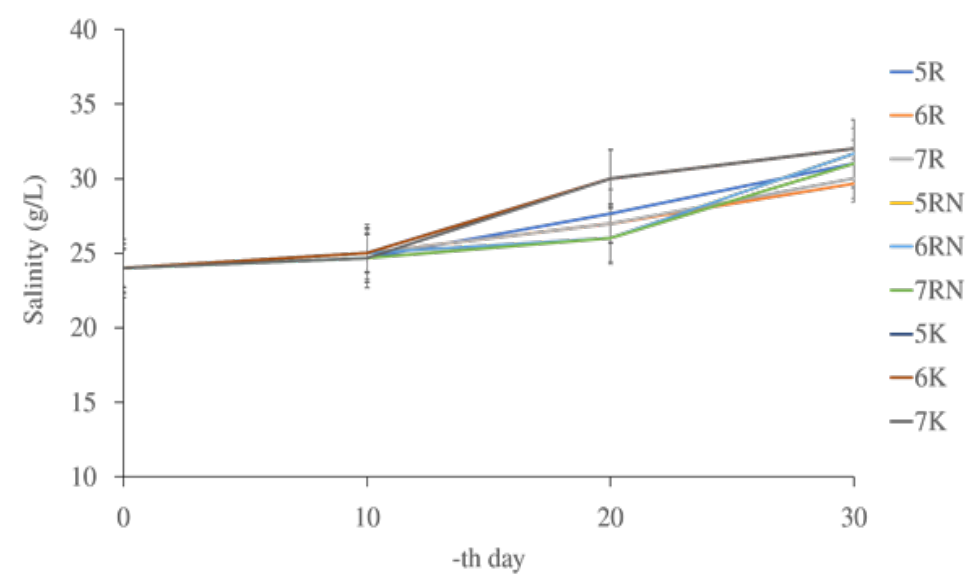

Figure 3. Salinity value during 30 days of hybrid brown-marbled grouper culture period
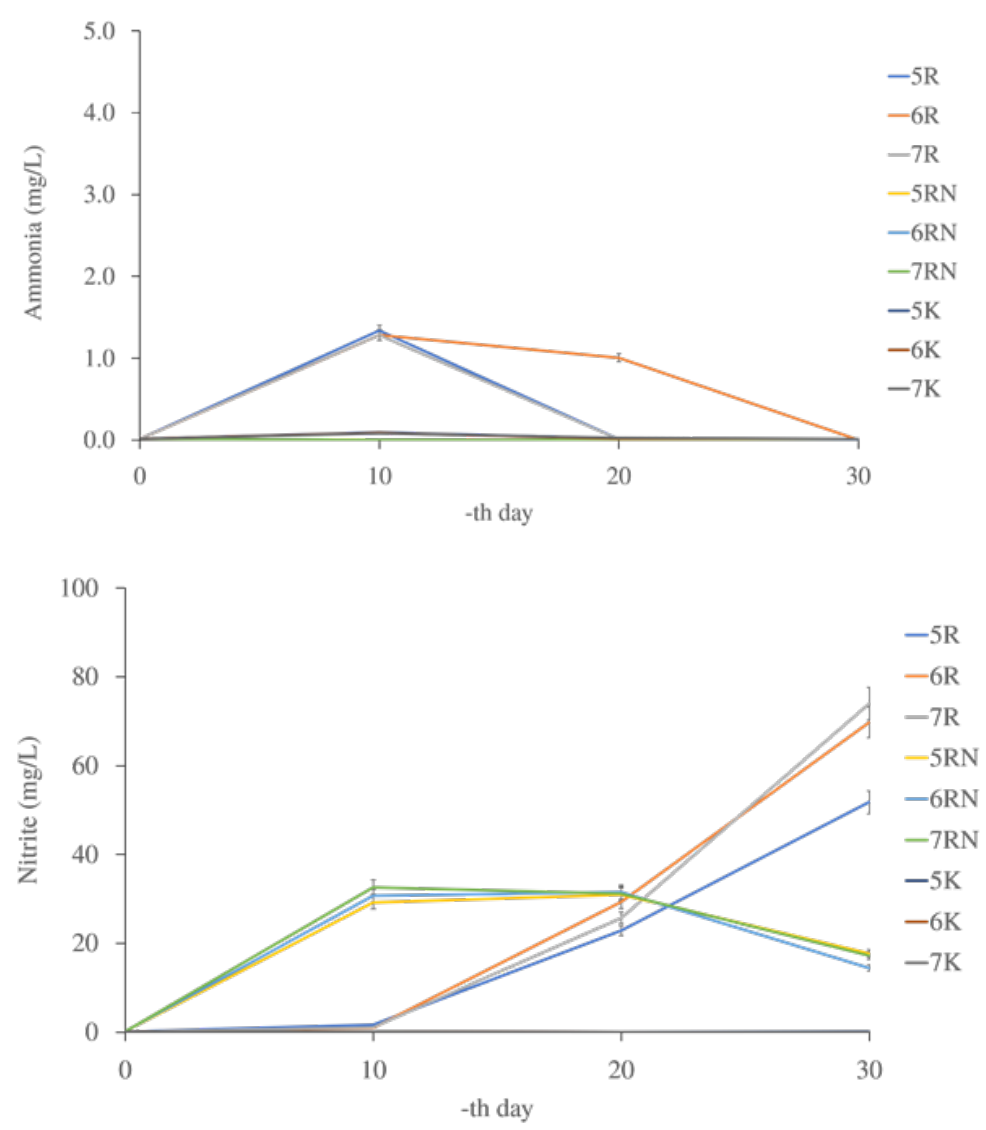

Figure 4. Ammonia and nitrite levels during 30 days of culture period 


\section{Growth performance}

After 30 days of hybrid brown-marbled grouper culture period in RAS with NBs obtained the best growth performance results (Table 3). The grouper fish fry reared in RAS with NBs also demonstrated a quite better productivity level (Table 4).

\section{Discussions}

Nanobubble application in recirculation system for hybrid brown-marbled grouper culture in various stocking densities will directly affect the environment or culture media. The environment designed by the system will influence fish stress and fish appetite. Moreover, the effect of recirculation system and utilization of nanobubble regulator with various stocking densities can be identified directly by producing different production performance.

Dissolved oxygen is a parameter that plays important role in water quality improvemet (Boyd, 2017), mainly on the fish culture activity. Therefore, increased dissolved oxygen becomes the main attention for grouper fish culture. The dissolved oxygen value during the experiment period tended to be stable in the culture media of hybrid brown-marbled grouper fish. However, the best result was obtained in RAS with nanobubble at different stocking density treatments.

Optimal dissolved oxygen for hybrid brown-marbled grouper growth has never been specifically studied. However, several studies mentioned that the dissolved oxygen condition of $5.2-6.2 \mathrm{mg} / \mathrm{L}$ showed a good growth for larvae until $3 \mathrm{~cm}$ fry (Ismi, 2010; Ismi et al., 2016). Furthermore, the dissolved oxygen standard used in hybrid grouper fry culture is suggested to be $>4 \mathrm{mg} / \mathrm{L}$ (SNI 8036.2:2014), while brownmarbled grouper fish is suggested to be $>5 \mathrm{mg} / \mathrm{L}$ (SNI 6488.3:2011). Overall, the dissolved oxygen level in all treatments can be said to follow the standard quality, even a higher value was found in nanobubble treatment at $500 \mathrm{fish} / \mathrm{m}^{3}(5 \mathrm{RN})$ at $11.75 \mathrm{mg} / \mathrm{L}$.

The acidity level or $\mathrm{pH}$ in the waters is one of the important chemical parameters in waters, mainly in grouper fish culture using recicurlation system. Imtolerable physical and chemical water

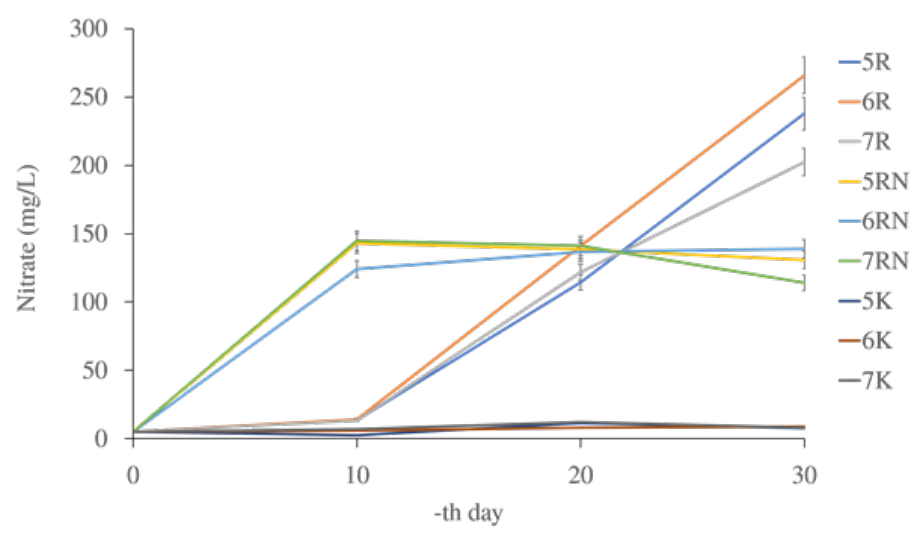

Figure 4. [continue] Nitrate levels during 30 days of culture period

Table 3. Length, weight, SGR, and FCR of grouper fish cultured in different systems and stocking densities

\begin{tabular}{ccccccc}
\hline Treatment & Initial length & Final length & Initial weight & Final weight & SGR (\%/day) & FCR \\
\hline 5R & $3.52 \pm 0.04^{\mathrm{a}}$ & $7.55 \pm 0.27^{\mathrm{a}}$ & $0.99 \pm 0.03^{\mathrm{a}}$ & $8.95 \pm 0.92^{\mathrm{a}}$ & $3.67 \pm 0.17^{\mathrm{a}}$ & $1.13 \pm 0.16^{\mathrm{ab}}$ \\
$6 \mathrm{R}$ & $3.5 \pm 0.08^{\mathrm{a}}$ & $7.56 \pm 0.15^{\mathrm{a}}$ & $1.00 \pm 0.08^{\mathrm{a}}$ & $8.5 \pm 0.22^{\mathrm{a}}$ & $3.57 \pm 0.16^{\mathrm{a}}$ & $1.32 \pm 0.17^{\mathrm{bc}}$ \\
$7 \mathrm{R}$ & $3.52 \pm 0.07^{\mathrm{a}}$ & $7.36 \pm 0.09^{\mathrm{a}}$ & $0.97 \pm 0.02^{\mathrm{a}}$ & $8.16 \pm 0.84^{\mathrm{a}}$ & $3.55 \pm 0.18^{\mathrm{a}}$ & $1.57 \pm 0.14^{\mathrm{d}}$ \\
$5 \mathrm{RN}$ & $3.51 \pm 0.06^{\mathrm{a}}$ & $8.86 \pm 0.03^{\mathrm{b}}$ & $0.99 \pm 0.02^{\mathrm{a}}$ & $12.2 \pm 0.01^{\mathrm{b}}$ & $4.19 \pm 0.04^{\mathrm{b}}$ & $1.04 \pm 0.01^{\mathrm{a}}$ \\
$6 \mathrm{RN}$ & $3.55 \pm 0.02^{\mathrm{a}}$ & $8.92 \pm 0.02^{\mathrm{b}}$ & $0.94 \pm 0.03^{\mathrm{a}}$ & $12.03 \pm 0.58^{\mathrm{b}}$ & $4.25 \pm 0.07^{\mathrm{b}}$ & $1.11 \pm 0.06^{\mathrm{ab}}$ \\
$7 \mathrm{RN}$ & $3.54 \pm 0.04^{\mathrm{a}}$ & $8.93 \pm 0.04^{\mathrm{b}}$ & $0.96 \pm 0.03^{\mathrm{a}}$ & $12.35 \pm 0.47^{\mathrm{b}}$ & $4.25 \pm 0.09^{\mathrm{b}}$ & $1.27 \pm 0.06^{\mathrm{b}}$ \\
$5 \mathrm{~K}$ & $3.49 \pm 0.05^{\mathrm{a}}$ & $7.56 \pm 0.26^{\mathrm{a}}$ & $0.97 \pm 0.03^{\mathrm{a}}$ & $8.86 \pm 0.21^{\mathrm{a}}$ & $3.69 \pm 0.08^{\mathrm{a}}$ & $1.53 \pm 0.13^{\text {cd }}$ \\
$6 \mathrm{~K}$ & $3.46 \pm 0.01^{\mathrm{a}}$ & $7.33 \pm 0.36^{\mathrm{a}}$ & $1.02 \pm 0.09^{\mathrm{a}}$ & $8.27 \pm 0.48^{\mathrm{a}}$ & $3.49 \pm 0.04^{\mathrm{a}}$ & $1.55 \pm 0.15^{\text {cd }}$ \\
$7 \mathrm{~K}$ & $3.51 \pm 0.04^{\mathrm{a}}$ & $7.34 \pm 0.21^{\mathrm{a}}$ & $0.96 \pm 0.02^{\mathrm{a}}$ & $8.33 \pm 0.36^{\mathrm{a}}$ & $3.60 \pm 0.04^{\mathrm{a}}$ & $1.51 \pm 0.13^{\mathrm{d}}$ \\
\hline
\end{tabular}

Different superscript letters after average \pm standard error values in the same column show a significant different $(\mathrm{P}<0.05)$. SGR: specific growth rate and FCR: feed conversion ratio. 
quality changes including $\mathrm{pH}$ value in grouper fish culture media can affect the grouper fish gills and oxygen consumption level. The lowest $\mathrm{pH}$ value obtained during the study was 7.0 in the $7 \mathrm{RN}$ treatment. Meanwhile, $\mathrm{pH}$ in all control treatments with various stocking densities tended to be more stable, as control treatments applied $200 \%$ water exchange per day. Water exchange and circulation systems can provide an optimal water quality for fish culture. However, it can become a bad impact on the environment if being maintained improperly and the aquaculture industry pollution has been lately become a big problem for the water environment (Wang et al., 2018). The suggested $\mathrm{pH}$ value for hybrid grouper is 7.5-8.5 (SNI 8036.2:2014) as the standard for one of the cross-bred fish cultures. The 5RN, $6 \mathrm{RN}$, and $7 \mathrm{RN}$ treatments obtained a lower $\mathrm{pH}$ value than the suggested $\mathrm{pH}$ value. However, this $\mathrm{pH}$ value was still in an optimum limit for hybrid brown-marbled grouper based on blood glucose level, oxygen consumption level, and gill histology analyses. Moreover, it can also be proven on the production performance discussed below.

Salinity value should be noticed in marinefish culture as increased or decreased salinity affect the fish osmoregulation system. Salinity is an important abiotic factor for fish culture that can affect fish growth and physiological performance. In addition, the hybrid brown-marbled grouper has large osmotic gradient. The recirculation system used affects the evaporation level that increases the salinity level compared to the non-flow water system without water exchange. Optimal salinity for hybrid brown-marbled grouper culture needs a further study, but the data proves that the hybrid brown-marbled grouper has a high tolerance on salinity range. The salinity level applied based SNI 6488.3:2011 for brown-marbled grouper ( $E$. fuscoguttatus) is $24.0-33.0 \mathrm{~g} / \mathrm{L}$.

Ammonia, nitrite, and nitrate levels are physical-chemical water quality parameters that become a challenge in recirculation system with high dissolved oxygen concentration. Ammonia and nitrite accumulations become the highest toxicant compounds for fish, shrimps, and other aquatic organisms (Shao et al., 2019), that will inhibit the RAS application in the aquaculture industry. The ammonia level during the experiment was fluctuating in RAS without NBs treatments. The highest ammonia level on the 10th day of culture obtained that all RAS without NBs treatments in various stocking densities reached at $1.340 \mathrm{mg} / \mathrm{L}$ (5R treatment). Decreased ammonia level in RAS without NBs treatments occurred on the 20th day of culture, except in the 6R treatment, which obtained a value of $1.007 \mathrm{mg} / \mathrm{L}$. RAS with NBs and control treatments tended to be stable at 0.001-0.096 $\mathrm{mg} / \mathrm{L}$ from the beginning to the end of the culture period. The suggested ammonia level in some grouper fish fry cultures are below $0.01 \mathrm{mg} / \mathrm{L}$ (SNI 6488.3:2011; SNI 8036.2:2014). The nitrite level during the experiment showed that the $5 \mathrm{R}$, $6 \mathrm{R}$, and $7 \mathrm{R}$ treatments had nitrite levels at 51.780, 69.720 dan $73.397 \mathrm{mg} / \mathrm{L}$. Meanwhile, ammonia level during the culture period tended to be stable in all control treatments at $0.001-0.097 \mathrm{mg} / \mathrm{L}$. Nitrite levels in RAS with NBs increased on the 20th day of culture and decreased entirely until the end of culture period. The nitrate level during the experiment showed that the RAS treatments obtained the highest nitrate level in $600 \mathrm{fish} / \mathrm{m}^{3}$ stocking density at $265.73 \mathrm{mg} / \mathrm{L}$.

Table 4. FLD, FWD, SR, productivity, and growth pattern of grouper fish cultured in different systems and stocking densities

\begin{tabular}{ccccc}
\hline Treatment & FLD $(\%)$ & FWD $(\%)$ & SR $(\%)$ & Productivity $\left(\mathrm{kg} / \mathrm{m}^{2}\right)$ \\
\hline $5 \mathrm{R}$ & $5.09 \pm 2.47^{\mathrm{b}}$ & $12.14 \pm 2.39^{\mathrm{bc}}$ & $100 \pm 0.00^{\mathrm{d}}$ & $2.02 \pm 0.71^{\mathrm{a}}$ \\
$6 \mathrm{R}$ & $4.78 \pm 0.50^{\mathrm{b}}$ & $9.35 \pm 3.45^{\mathrm{abc}}$ & $99.34 \pm 0.28^{\mathrm{d}}$ & $1.91 \pm 0.64^{\mathrm{a}}$ \\
$7 \mathrm{R}$ & $4.50 \pm 0.62^{\mathrm{b}}$ & $12.44 \pm 0.77^{\mathrm{c}}$ & $99.44 \pm 0.49^{\mathrm{d}}$ & $1.85 \pm 0.61^{\mathrm{a}}$ \\
$5 \mathrm{RN}$ & $1.87 \pm 0.06^{\mathrm{a}}$ & $9.15 \pm 2.32^{\mathrm{abc}}$ & $99.8 \pm 0.34^{\mathrm{d}}$ & $2.75 \pm 1.09^{\mathrm{c}}$ \\
$6 \mathrm{RN}$ & $3.06 \pm 0.98^{\mathrm{ab}}$ & $7.61 \pm 0.44^{\mathrm{ab}}$ & $100 \pm 0.00^{\mathrm{d}}$ & $2.78 \pm 1.11^{\mathrm{c}}$ \\
$7 \mathrm{RN}$ & $2.12 \pm 0.20^{\mathrm{a}}$ & $6.50 \pm 1.77^{\mathrm{a}}$ & $100 \pm 0.00^{\mathrm{d}}$ & $2.73 \pm 1.09^{\mathrm{c}}$ \\
$5 \mathrm{~K}$ & $3.62 \pm 0.62^{\mathrm{ab}}$ & $8.86 \pm 0.21^{\mathrm{abc}}$ & $97.83 \pm 1.23^{\mathrm{c}}$ & $2.00 \pm 0.68^{\mathrm{a}}$ \\
$6 \mathrm{~K}$ & $4.74 \pm 0.06^{\mathrm{b}}$ & $8.27 \pm 0.48^{\mathrm{bc}}$ & $95.89 \pm 0.75^{\mathrm{b}}$ & $2.24 \pm 0.82^{\mathrm{b}}$ \\
$7 \mathrm{~K}$ & $4.70 \pm 0.98^{\mathrm{b}}$ & $8.33 \pm 0.36^{\mathrm{abc}}$ & $92.23 \pm 1.29^{\mathrm{a}}$ & $2.62 \pm 1.03^{\mathrm{c}}$ \\
\hline
\end{tabular}

Different superscript letters after average \pm standard error values in the same column show a significant different $(\mathrm{P}<0.05)$. FLD: fish length diversity, FWD: fish weight diversity, and SR: survival rate. 
The fish specific growth rate produced in this study was among $3.49-4.25 \%$ /hari with the highest value was obtained from the nanobubble treatments. Based on the previous studies, the specific growth rate in juvenile hybrid grouper fish (E. fuscoguttatus $\varnothing$ × E. lanceolatus $\widehat{\partial}$ ) was around $3.13 \pm 0.04 \% /$ day (Sutarmat \& Yudha, 2013; Marzuki et al., 2020; He et al., 2021). The nanobubble treatments showed that the utilization of this equipment can provide a better feed conversion ratio. The best feed conversion ratio in this study was obtained from the $5 \mathrm{RN}$ treatment at $1.04 \pm 0.01$. The feed conversion ratio on the previous study in juvenile hybrid grouper fish $(E$. fuscoguttatus $\bigcirc$ x E. lanceolatus $\left.\bigcirc^{\hat{O}}\right)$ was $1.04(\mathrm{He}$ et al., 2021).

Smaller length and weight diversities indicates that fish high uniformity level. The best length diversity was obtained from the 5RN treatment at $1.87 \pm 0.06 \%$ and the weight diversity was obtained from the $7 \mathrm{RN}$ treatment at $6.50 \pm 1.77 \%$. Size variation is influenced by diets and water quality in optimal condition that will produce fish biomass with relatively uniform size (Lante et al., 2011). Based on the field observation of grouper fry agribusiness, consumers prefer choosing fry in uniform size, specifically in length size. Health conidition can be monitored thorugh physical capability in sustaining the fish survival rate (Muthmainnah, 2013).

The survival rate in this study was among $92.23 \pm 1.29-100.00 \pm 0.00 \%$. The fish survival rate was among the range limit based on the previous studies, namely at $66.67-100 \%$ (Yin et al., 2018; Riduan et al., 2019; Sun et al., 2019; Zhou et al., 2019; Tan et al., 2019). The survival rate of juvenile hybrid grouper (E. fuscoguttatus +

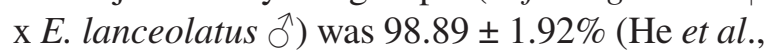
2021). Survival rate is influenced by adaptability, physical conditions, age, competition, stocking density, handling, parasites, and water quality (Ismi et al., 2016). The production performance parameters in system can be seen also through its productivity level. The highest productivity level in this study was obtained from the 6RN treatment that could produce the highest grouper fish fry biomass at $2.78 \pm 1.11 \mathrm{~kg} / \mathrm{m}^{2}$.

\section{CONCLUSION}

The RAS with NBs application for juvenile hybrid brown-marbled grouper culture obtained a better production performance, mainly in growth performance and productivity.

\section{ACKNOWLEDGMENTS}

Authors would like to thank the Head of Aquaculture Study Program, IPB University, Bogor, Center for Brackishwater Aquaculture Situbondo, and Nanobubble.id for facilitating and supporting this project.

\section{REFERENCES}

Afero F. 2012. Analisa ekonomi budidaya kerapu macan Epinephelus fuscoguttatus dan kerapu bebek Cromileptes altivelis dalam keramba jaring apung di indonesia. Depik 1: 10-21.

Agarwal A, Ng WJ, Liu Y. 2011. Principle and applications of microbubble and nanobubble technology for water treatment. Chemosphere 84: 1175-1180.

Akbar S, Marsoedi, Soemarno, Kusnendar E. 2012. Pengaruh pemberian pakan yang berbeda terhadap pertumbuhan ikan kerapu macan Ephinephelus fuscoguttatus pada fase pendederan di keramba jaring apung. Teknologi Pangan: Media Informasi dan Komunikasi Ilmiah Teknologi Pertanian 4: 93-101.

Boyd CE. 2017. Fish Diseases: General Relationship Between Water Quality and Aquaculture Performance in Ponds. United States (US): Aburn University, Academic Press. 147-166 hlm.

Dien LT, Linh NV, Sangpo P, Senapin S, StHilaire S, Rodkhum C, Dong HT. 2021. Ozone nanobubble treatments improve survivability of Nile tilapia Oreochromis niloticus challenged with a pathogenic multidrug-resistant Aeromonas hydrophila. Journal of Fish Diseases 44: 1435-1447.

[DJPB] Direktorat Jendral Perikanan Budidaya. 2018. Pemberlakuan permen 32/2016 demi perbaikan tata kelola perdagangan ekspor ikan kerapu. [terhubung berkala] https://kkp.go.id/ artikel [5 Januari 2020].

Ebina K, Shi K, Hirao M, Hashimoto J, Kawato Y, Kaneshiro S, Morimoto T, Koizumi K, Yoshikawa H. 2013. Oxygen and air nanobubble water solution promoted the growth of plants, fishes, and mice. PLoS ONE 8: e65339.

Effendi I, Diatin I, Budiardi T, Haderoseyani Y. 2021. Grouper nursery development through group capacity building for leading commodity strengthen of Seribu Islands Administrative District, Jakarta. Agrokreatif Jurnal Ilmiah Pengabdian kepada Masyarakat 7: 148-161. 
Eriksson JC, Ljunggren S. 1999. On the mechanically unstable free energy minimum of a gas bubble which is submerged in water and adheres to a hydrophobic wall. Colloids and Surfaces a-Physicochemical and Engineering Aspects 159: 159-163.

Goddard S. 1996. Feed Management in Intensive Aquaculture. Chapman \& Hall, New York, $194 \mathrm{pp}$

He Y, Guo X, Tan B, Dong X, Yang Q, Liu H, Zhang S, Chi S. 2021. Replacing fish meal with fermented rice protein in diet for hybrid grouper (Epinephelus fuscoguttatus O $\mathrm{x}$ Epinephelus lanceolatus ${ }^{\Uparrow}$ ): Effect on growth, digesties and absorption capacities, inflammatory-related gane expression, and intestinal microbiota. Aquaculture Reports 19: 100603.

Hong J, Chen C, Liu S, Fu Z, Han M, Wang Y, Gu Z, Ma Z. 2019. Impact of fish density on water quality and physiological response of golden pompano Trachinotus ovatus flingerlings during transportation. Aquaculture 507: 260265.

Imaizumi $\mathrm{K}$, Tinwongger $\mathrm{S}$, Kondo $\mathrm{H}$, Hirono I. 2018. Disinfection of an EMS/AHPND strain of Vibrio parahaemolyticus using ozone nanobubbles. Journal of Fish Diseases 41: 725-727.

Ismi S. 2010. Pendederan kerapu bebek Cromileptes altivelis sebagai salah satu usaha untuk meningkatkan pendapatan petani pada pembenihan ikan laut. Dalam: Prosiding Simposium Nasional Pembangunan Sektor Kelautan dan Perikanan Kawasan Timur Indonesia. Balitbang Kelautan dan Perikanan, Jakarta (ID).

Ismi S, Kusumawati D, Asih YN. 2016. Pengaruh lama waktu pemuasaan dan beda kepadatan benih kerapu pada transportasi secara tertutup. Jurnal Ilmu dan Teknologi Kelautan Tropis 2: 625-632.

Lante S, Adhiyudanto NB, Palinggi NN. 2011. Pendederan ikan beronang, Siganus guttatus dengan ukuran tubuh benih yang berbeda. Prosiding Forum Inovasi Teknologi Akuakultur 419-423.

Lawson TB. 1995. Recirculating Aquaculture Systems. In: Fundamentals of Aquacultural Engineering. Springer, Boston, MA. https:// doi.org/10.1007/978-1-4615-7047-9_10

Linh NV, Panphut W, Thapinta A, Senapin S, St-Hilaire S, Rodkhum C, Dong HT. 2021. Ozone nanobubble modulates the innate defense system of Nile tilapia Oreochromis niloticus against Streptococcus agalactiae. Fish and Shellfish Immunology 112: 64-73.

Losordo T, DeLong D, Guerdat T. 2009. New Technologies in Aquaculture: Improving production efficiency, quality and environmental management 1 st edition. Cambridge (UK): Woodhead Publishing. 945$983 \mathrm{hlm}$.

Mahasri G, Saskia A, Apandi PS, Dewi NN, Rozi, Usuman NM. Development of an aquaculture system using nanobubble technology for the optimation of dissolved oxygen in culture media for nile tilapia Oreochromis niloticus. IOP Conf. Series: Earth and Environmental Science 137: 012046.

Marzuqi M, Haryanti H, Astuti NWW, Giri N, Mahardika K. 2020. Growth performance and feed nutrient digestibility of hybrid grouper (Epinephelus fuscoguttatus $\mathrm{x}$ Epinephelus polyphekadion) fed with diets supplemented with probiotic bacteria and papain enzyme. Media Akuakultur 15: 29-37.

Matsuki N, Ichiba S, Ishikawa T, Nagano O, Takeda M, Ujike Y, Yamaguchi T. 2012. Blood oxygenation using microbubble suspensions. European Biophysics Journal 41: 571-578.

Mauladani S, Rahmawati AI, Absirin MF, Saputra RN, Pratama AF, Hidayatullah, A, Dwiarto A, Syarif A, Junaedi H, Cahyadi D. 2020. Economic feasibility study of Litopenaeus vannamei shrimp farming: nanobubble investment in increasing harvest productivity. Jurnal Akuakultur Indonesia 19: 30-38.

Muthmainnah D. 2013. Hubungan panjang berat dan faktor kondisi ikan gabus, Channa striata Bloch, 1793 yang dibesarkan di Rawa Lebak, Provinsi Sumatera Selatan. DEPIK 2: 184190.

Nghia NH, Van PT, Giang PT, Hanh NT, StHilaire S, Domingos JA. 2021. Control of Vibrio parahaemolyticus (AHPND strain) and improvement of water quality using nanobubble technology. Aquaculture Research 2021: 1-13

Rahmaningsih S dan Ari AI. 2013. Pakan dan Pertumbuhan Ikan Kerapu Canatang (Epinephellus fuscoguttatus-lanceolatus). Ekologia 13: 25-30.

Rahmawati AI, Saputra RN, Hidayatullah A, Dwiarto A, Junaedi H, Cahyadi D, Saputra HKH, Prabowo W, Kartamiharja UKA, Shafira H. 2021. Enhancement of Penaeus vannamei shrimp growth using nanobubble in indoor 
raceway pond. Aquaculture and Fisheries 6: 277-282.

Riduan, Putra WKA, Yulianto T. 2019. Laju pertumbuhan dan kelangsungan hidup ikan kerapu cantang, Epinephelus lanceolatus $\delta^{\lambda}$ $\times$ Epinephelus fuscoguttatus 9 dengan teknik perendaman dan oral recombinant growth hormone (rGH). Intek Akuakultur 3: 16-24.

Saefulhak A. 2004. Metode pendugaan biomassa dan produktivitas udang vaname Litopenaeus vannamei pada tambak biocrete. Bogor (ID): Institut Pertanian Bogor.

Shabani F, Erikson U, Beli E, Rexhepi A. 2016. Live transport of rainbow trout Onchorhynchus mykiss and subsequent live storage in market: Water quality, stress and welfare considerations. Aquaculture 453: 110-115.

Shao Y, Zhang H, Buchanan I, Mohammed A, Liu Y. 2019. Comparison of extracellular polymeric substance (EPS) in nitrification and nitritation bioreactors. International Biodeterioration \& Biodegradation 143: 104713.

[SNI] Standar Nasional Indonesia. 2011. Ikan kerapu macan Epinehelus fuscoguttatus. Bagian 3: Produksi Benih. Badan Standarisasi Nasional, Jakarta.

[SNI] Standar Nasional Indonesia. 2014. Ikan kerapu Cantang (Epinehelus fuscoguttatus, Forsskal 1775 x Epinehpelus lanceolatus, Bloch 1790). Bagian 2: Produksi Benih Hibrida. Badan Standarisasi Nasional, Jakarta.

Sun Z, Tan X, Xu M, Liu Q, Ye H, Zou C, Zhou Y, Su N, Chen L, Wang A, Ye C. 2019. Effects of dietary Dandelion extracts on growth performance, liver histology, immunerelated gene expression and $\mathrm{CCl} 4$ resistance of hybrid grouper, Epinephelus lanceolatus $\widehat{\delta}$ $\times$ Epinephelus fuscoguttatus + . Fish and Shellfish Immunology 88: 126-134.

Sutarmat T, Yudha HT. 2013. Analisis keragaan pertumbuhan benih kerapu hibrida hasil hibridisasi kerapu macan
Epinephelus fuscoguttatus dengan kerapu kertang Epinephelus lanceolatus dan kerapu batik Epinephelus microdon. Jurnal Riset Akuakultur 8: 363-371.

Tan X, Sun Z, Ye C. 2019. Dietary Lycium barbarum extract administration improved growth, meat quality and lipid metabolism in hybrid grouper, Epinephelus lanceolatus $\hat{\sigma} \times$ Epinephelus fuscoguttatus $q$ fed high lipid diets. Aquaculture 504: 190-198.

Wang Z, Qian X, Xie S, Yun B. 2020. Changes of growth performance and plasma biochemical parameters of hybrid grouper, Epinephelus lanceolatus $\sigma^{\lambda} \times E$. fuscoguttatus $q$ in response to substitution of dietary fish meal with poultry by-product meal. Aquaculture Reports 18: 100516.

Xie F, Ai Q, Mai K, Xu W, Ma H. 2011. The optimal feeding frequency of large yellow croaker (Pseudosciaena crocea, Richardson) larvae. Aquaculture 311: 162-167.

Ye G, Dong X, Yang Q, Chi S, Liu H, Zhang H, Tan B, Zhang S. 2020. Dietary replacement of fish meal with peanut meal in juvenile hybrid grouper, Epinephelus lanceolatus $\widehat{\partial} \times$ E. fuscoguttatus O: Growth performance, immune response and intestinal microbiota. Aquaculture Reports 17: 100327.

Yin B, Liu H, Tan B, Dong X, Chi S, Yang Q, Zhang S, Chen L. 2018. Cottonseed protein concentrate (CPC) suppresses immune function in different intestinal segments of hybrid grouper, Epinephelus lanceolatus $\hat{O} \times$ E. fuscoguttatus of via TLR-2/MyD88 signaling pathways. Fish and Shellfish Immunology 81: 318-328.

Zhou Z, Wang X, Wu X, Gao Y, Li X, Dong Y, Yao W. 2019. Effects of dietary leucine levels on growth, feed utilization, Neuro-Endocrine growth axis and TOR-related signaling genes expression of juvenile hybrid grouper, Epinephelus lanceolatus $\widehat{\sigma} \times$ Epinephelus fuscoguttatus +. Aquaculture 504: 172-181. 